\title{
PERAN KOMISI PENANGGULANGAN AIDS DAERAH (KPAD) DALAM PENANGGULANGAN HIV DAN AIDS DI KABUPATEN KOTAWARINGIN TIMUR
}

\author{
ROLE OF AIDS PREVENTION AND CONTROL COMMISSION \\ IN EAST KOTAWARINGIN
}

\author{
Akhmad Rianor Asrari Puadi, M. Bagus Qomaruddin \\ Departemen Promosi Kesehatan dan Ilmu Perilaku, Fakultas \\ Kesehatan Masyarakat, Universitas Airlangga, Surabaya. Email: \\ asraripuadi@gmail.com
}

\begin{abstract}
Response to HIV and AIDS requires a approaches by the parties mutually integrated. Regional AIDS Commissions (KPAD) has a crucial role in the response to HIV and AIDS. This study aimed to describe the role of KPAD well as some of the factors inhibiting the implementation of the $H I V$ and AIDS in East Kotawaringin. Used qualitative methods to conduct a document review and indepth interviews with all five informants which is representative of several agencies that have links to the efforts to combat HIV and AIDS, with purposive sampling method. The Results were analyzed by means of reduction, presentation, and verifi cation of data. Results showed reduction carried through socialization and education about HIV and AIDS in the various elements of society, the establishment of working group of the Pal 12, formed the group "Concerned citizens of AIDS" as well as the ARV (Antiretroviral) services is not limited to a minimum value of CD4. The results showed that KPAD role in response to HIV and AIDS can not be implemented to the fullest, this is due to several obstacles, namely the existence of localization is an determinant spread of cases, the unavailability of services and $A R V$ in all health centers, the lack of cross-sectoral cooperation, financial support from the government is minimal, and the lack of HIV and AIDS Regional Regulation (Perda).
\end{abstract}

Keywords: Response to HIV and AIDS, AIDS Prevention and Control Commission (KPAD)

\begin{abstract}
Abstrak: Penanggulangan HIV \& AIDS memerlukan pendekatan oleh berbagai pihak yang terintegrasi. Komisi Penanggulangan AIDS Daerah (KPAD) memiliki peran krusial dalam penanggulangan HIV \& AIDS. Penelitian ini bertujuan untuk mendeskripsikan peran KPAD serta beberapa faktor penghambat pelaksanaan program penanggulangan HIV \& AIDS di Kabupaten Kotawaringin Timur. Menggunakan metode kualitatif dengan telaah dokumen dan in depth interview ke-5 orang informan yang terkait upaya penanggulangan HIV \& AIDS, dengan metode Purposive Sampling. Hasil dianalisis dengan cara reduksi, penyajian, dan verifikasi data. Hasil penelitian menunjukkan peran pencegahan HIV \& AIDS dilakukan melalui sosialisasi dan penyuluhan di berbagai elemen masyarakat, pembentukan Pokja di Pal 12, serta membentuk kelompok "Warga Peduli AIDS". Peran pengobatan atau rehabilitasi dilakukan dengan pelayanan ARV (Antiretroviral) yang tidak terbatas pada nilai minimal CD4. Dari hasil penelitian diperoleh bahwa peran KPAD dalam penanggulangan HIV \& AIDS belum dilaksanakan secara maksimal, hal ini disebabkan oleh beberapa hambatan, yaitu keberadaan lokalisasi yang menjadi determinan penyebaran kasus, belum tersedianya pusat rehabilitasi serta pelayanan ARV di semua Puskesmas, kerja sama lintas sektoral yang kurang, dukungan dana pemerintah yang minim, serta Peraturan Daerah (Perda) penanggulangan HIV \& AIDS yang belum tersedia.
\end{abstract}

Kata kunci: Penanggulangan HIV \& AIDS, KPAD

\section{PENDAHULUAN}

Kesehatan adalah hak asasi yang melekat pada setiap manusia, baik dalam lingkup kesehatan individual maupun kelompok (keluarga). Tanpa kesehatan yang baik, setiap orang tidak akan dapat menjalankan aktivitas dengan baik.
Pemahaman yang rendah akan urgensi kesehatan membuat seseorang acuh dan memandang sebelah mata dengan permasalahan kesehatan di lingkungan sekitar mereka atau yang lazim disebut sebagai paradigma sehat dan sakit dalam konsep kesehatan masyarakat. 
Salah satu penyakit yang hingga kini menjadi permasalahan besar dan mendapat perhatian khusus dari pemerintah adalah penyakit HIV \& AIDS. HIV \& AIDS merupakan isu kesehatan yang cukup sensitif dan penting untuk dibicarakan. Fenomena Gunung es yang menjadi ciri khas dari perkembangan kasus HIV \& AIDS, ditandai dengan persebaran kasus HIV \& AIDS yang tidak dapat diprediksi saat fase awal namun baru akan terlihat dan teridentifikasi ketika telah terjadi infeksi serta telah dinyatakan positif terkena HIV \& AIDS. Selain itu, stigma dan diskriminasi di masyarakat yang masih banyak dialami penderita dan keluarga menjadi persoalan tersendiri. Semakin tinggi stigma oleh masyarakat dan lingkungan menyebabkan timbul banyak perlakuan diskriminatif di beberapa bidang, dimulai dalam hal perawatan, pengobatan, pendidikan, serta pekerjaan. Penyakit yang menyerang system kekebalan tubuh ini diperkirakan telah menginfeksi lebih dari 3040 juta penduduk yang tersebar hampir di seluruh negara di dunia dan sekitar $80 \%$ terjadi di beberapa negara berkembang terutama negara bagian Asia (Mynarwati, 2000).

Di Indonesia kasus HIV \& AIDS masih menjadi masalah yang menakutkan, hal ini terbukti di setiap tahun trend kasus HIV

\& AIDS semakin meningkat, baik jumlah maupun persebaran. Penyakit HIV \& AIDS tidak lagi hanya menyerang kelompok rentan remaja dan dewasa namun juga telah menyerang kelompok usia anak dan bayi yang ditemukan meninggal karena AIDS. Komisi Penanggulangan AIDS (KPA) dalam Strategi Nasional (STRANAS) Penanggulangan HIV \& AIDS 2007-2010 menyebutkan bahwa sekitar 2000 anak di bawah 15 tahun telah tertular virus HIV, terutama berasal dari penularan Bayi ke Ibu, menewaskan 1400 Anak di bawah 15 tahun, dan menginfeksi lebih dari 6000 orang dalam usia produktif yaitu antara 15-24 tahun yang juga mayoritas dari orang-orang yang hidup dengan HIV \& AIDS (ODHA) (KPA, 2015). Sedangkan dari laporan Ditjen PP dan PL Kemerdekaan RI pada tahun 2014 jumlah kumulatif kasus HIV \& AIDS yang terlapor hingga september 2014 adalah 150,926 kasus HIV dan 55,799 kasus
AIDS dengan jumlah kematian yaitu 9,796 kematian.

Memahami permasalahan HIV \& AIDS tidak lagi hanya bisa dipandang sebagai masalah kesehatan semata, akan tetapi juga harus dipandang sebagai permasalahan sosial yang sangat kompleks (Ananda, 2014). Upaya pencegahan dan penanggulangan HIV \& AIDS membutuhkan berbagai pendekatan yang diselenggarakan oleh Stake holder yang saling terintegrasi. Masyarakat ditempatkan sebagai pemegang peran utama dengan pembinaan dan arahan dari berbagai sektor pemerintah terkait.

Peran menurut Soekamto (2010) merupakan sebuah aspek yang dinamis dari kedudukan (status). Apabila hak dan kewajiban telah dilaksanakan oleh sesorang sesuai dengan kedudukannya, maka seseorang tersebut dapat dikatakan telah menjalankan sebuah peran. Lebih lanjut dijelaskan peran mencakup tiga hal yaitu : Pertama, peran meliputi berbagai norma yang dihubungkan dengan posisi atau tempat seseorang dalam masyarakat. Peran dalam pengertian ini merupakan rangkaian dari sebuah sistem atau peraturan yang menjadi pedoman dan membimbing seseorang dalam kehidupan bermasyarakat. Kedua, peran merupakan suatu konsep tentang hal apa yang dapat dilakukan oleh seseorang dalam kehidupan bermasyarakat sebagai bagian organisasi. Terakhir, peran adalah perilaku seseorang yang menjadi bagian penting dalam struktur sosial masyarakat.

Sesuai dengan Peraturan Presiden (Perpres) No. 75 Tahun 2006 yang memuat aturan tentang Komisi Penanggulangan AIDS Nasional, penanggulangan HIV \& AIDS merupakan upaya yang dilaksanakan KPA untuk mencegah, menghadapi, dan mengatasi suatu keadaan yang mengancam kesehatan masyarakat terhadap dampak akibat orang yang berperilaku seksual dengan berganti-ganti pasangan tanpa menggunakan kondom, dan pengguna narkoba suntik yang menggunakan jarum suntik secara bersama. KPA dalam menjalankan fungsinya harus berdasar pada beberapa prinsip dasar penanggulangan HIV \& AIDS, yaitu : Pertama, upaya penanggulangan HIV \& AIDS dilaksanakan secara bersama dari dan oleh masyarakat beserta pemerintah. 
Kedua, setiap upaya penanggulangan HIV \& AIDS harus mencerminkan nilai agama dan budaya yang dianut dan berkembang dalam tatanan masyarakat Indonesia. Ketiga, setiap kegiatan dibuat serta diarahkan untuk mempertahankan dan memperkukuh ketahanan dan kesejahteraan keluarga, serta sistem dukungan sosial yang mengakar pada masyarakat Indonesia. Keempat, pencegahan HIV \& AIDS diarahkan pada upaya preventif dengan melakukan pendidikan serta penyuluhan untuk memantapkan perilaku masyarakat yang baik dan mengubah perilaku masyarakat yang rentan serta berisiko tinggi terhadap perkembangan HIV $\&$ AIDS.

KPA melakukan kegiatan pencegahan dan penanggulangan tersebut dengan melakukan program yang bertanggung jawab dengan tanpa membahayakan hak privasi seseorang. Hal ini telah diatur dalam Pasal 1 ayat 6, Undang-undang Kesehatan No 36 Tahun 2009 tentang Wabah Penyakit Menular yang menyatakan bahwa upaya penanggulangan adalah segala upaya yang ditujukan untuk memperkecil angka kematian, membatasi penularan serta penyebaran penyakit, agar wabah tidak meluas ke daerah lain.

Di tingkat provinsi menurut data Profil Kesehatan Provinsi Kalimantan Tengah pada tahun 2012 yang tersaji pada Tabel 1 , disebutkan terdapat sebanyak 44 orang penderita HIV \& AIDS yang ada di Kabupaten Kotawaringin Timur. Hal ini sekaligus menempatkan Kabupaten Kotawaringin Timur pada posisi pertama dengan jumlah kasus HIV \& AIDS terbanyak setingkat Provinsi Kalimantan Tengah. Hal ini berkaitan erat dengan persepsi buruk yang berkembang di masyarakat, yaitu ketakutan akan dijauhi dan dikucilkan masyarakat jika mengidap penyakit HIV \& AIDS.

Sementara dalam laporan Profil Kesehatan Kabupaten Kotawaringin Timur pada tahun 2014 disebutkan bahwa total 35 kasus HIV didominasi oleh kelompok produktif, usia 20-29 tahun. Sebanyak 26 kasus ada di jenis kelamin perempuan dan 9 kasus ada di jenis kelamin laki-laki. Sedangkan untuk jumlah kasus AIDS didominasi oleh jenis kelamin laki-laki yaitu
Tabel 1. Jumlah kasus HIV \& AIDS menurut kabupaten di Provinsi Kalimantan Tengah.

\begin{tabular}{lrcc}
\hline \multicolumn{1}{c}{ Kabupaten } & \multicolumn{2}{c}{ Jumlah } & \\
& Kasus & Jumlah \\
& HIV & AIDS & Kematian \\
\hline Kotawaringin Barat & 24 & 3 & 3 \\
Lamandau & 0 & 1 & 0 \\
Sukamara & 0 & 0 & 0 \\
Kotawaringin Timur & 43 & 1 & 1 \\
Seruyan & 0 & 0 & 0 \\
Katingan & 3 & 1 & 1 \\
Kapuas & 0 & 0 & 0 \\
Pulang Pisau & 0 & 0 & 0 \\
Gunung Mas & 2 & 0 & 0 \\
Barito Selatan & 0 & 0 & 0 \\
Barito Timur & 0 & 2 & 1 \\
Barito Utara & 0 & 1 & 1 \\
Murung Raya & 0 & 0 & 0 \\
Palangka Raya & 24 & 5 & 4 \\
\hline Jumlah (Provinsi) & 96 & 14 & 11 \\
\hline
\end{tabular}

Sumber: Profil Kesehatan Provinsi Kalimantan

Tengah 2012

dengan 2 kasus dan tidak ditemukan kasus pada jenis kelamin perempuan.

Menurut Mynarwati (2000), perkembangan dan penyebaran HIV \& AIDS terjadi karena pertama, industri seks komersial yang semakin berkembang di Indonesia. Kedua, semakin banyak orang yang sering bepergian dan melakukan hubungan seksual yang kurang baik, yaitu hubungan seksual dengan pasangan yang berganti-ganti. Ketiga, terjadi peningkatan insiden Penyakit Menular Seksual (PMS). Keempat, orang Indonesia yang memiliki perilaku risiko tinggi jarang yang berkenan menggunakan kondom sebagai alat pengaman. Kelima, sarana pelayanan fasilitas kesehatan yang tidak selalu memperhatikan dan menggunakan prosedur yang steril, yaitu dengan peralatan kesehatan dan prinsip kerja yang memprioritaskan tingkat kesterilan. Keenam, semakin tinggi angka hubungan seksual premarital (di luar nikah) yang marak terjadi di kalangan usia remaja dan pemuda. Serta terakhir, tingkat pengetahuan dan kepedulian oleh masyarakat umum yang masih rendah terhadap permasalahan HIV \& AIDS, baik yang terdapat di kalangan masyarakat 
maupun yang terdapat di sebagian besar pejabat pemerintah. Padahal para pejabat itulah yang memegang peranan penting dalam perumusan strategi dan kebijakan penanggulangan HIV \& AIDS.

Oleh karena itu, kejadian dan penyebaran kasus HIV \& AIDS perlu segera ditangani secara cepat dan tepat, mengingat implikasi negatif yang tidak hanya berdampak pada kesehatan masyarakat namun juga pada berbagai aspek penting lain, baik di bidang sosial, ekonomi dan politik, yang berpengaruh penting terhadap pembangunan nasional dan pembangunan daerah.

Berdasarkan kondisi dan fenomena yang sangat mengkhawatirkan tersebut penelitian ini dilakukan untuk mengetahui dan mengkaji bagaimana peran, serta berbagai faktor apa saja penghambat KPAD dalam upaya penanggulangan HIV \& AIDS di Kabupaten Kotawaringin Timur.

\section{METODE}

Penelitian ini dilakukan di daerah Kabupaten Kotawaringin Timur Kalimantan Tengah pada bulan AgustusSeptember 2016. Metode penelitian yang digunakan menggunakan metode kualitatif untuk menggali lebih dalam peran KPAD dalam upaya penanggulangan HIV \& AIDS di Kabupaten Kotawaringin Timur. Subyek diambil dengan metode purposive sampling. Variabel yang diteliti meliputi; Peran dalam pencegahan, Peran dalam pengobatan atau rehabilitasi serta kendala atau hambatan yang dihadapi KPAD dalam penanggulangan HIV \& AIDS.

Data primer didapatkan dengan melakukan in depth interview ke-5 orang informan yang merupakan representatif dari beberapa lembaga yang mempunyai kaitan terhadap upaya dan kebijakan penanggulangan HIV \& AIDS di Kabupaten Kotawaringin Timur , yaitu Ketua dan anggota Komisi DPRD Kabupaten Kotawaringin Timur Bidang Kesejahteraan Rakyat (Kesra), Asisten Pemerintah Kabupaten (Pemkab) Kotawaringin Timur Bidang Kesra, Kepala Dinas Kesehatan Kabupaten Kotawaringin Timur, Sekretaris KPAD Kabupaten Kotawaringin Timur.
Data sekunder didapat dari telaah dokumen antara lain: Panduan Elemen-elemen Pokok Pembentukan Peraturan Daerah Tentang Penanggulangan HIV \& AIDS, Profil Kesehatan Provinsi Kalimantan Tengah tahun 2012, Profil Kesehatan Kabupaten Kotawaringin Timur tahun 2014, Undang-undang No. 12 Tahun 2011 tentang Pembentukan Peraturan Perundang -undangan. Selanjutnya, hasil penelitian dianalisis dengan melakukan reduksi data, penyajian data, dan verifikasi data.

\section{HASIL PENELITIAN}

Peran utama KPAD dalam upaya penanggulangan HIV \& AIDS adalah pencegahan. Dari hasil penelitian Puadi (2016), peran KPAD Kabupaten Kotawaringin Timur dalam pencegahan HIV \& AIDS dilakukan dengan melaksanakan kebijakan dan berbagai kegiatan yang mendukung upaya pencegahan dan penanggulangan HIV \& AIDS, baik secara program maupun kegiatan yang dilakukan dengan melibatkan peran serta masyarakat. KPAD Kabupaten Kotawaringin Timur bekerjasama dengan beberapa lembaga dan komunitas dalam upaya promosi kesehatan dan penyuluhan ke masyakarat, hal ini dilakukan guna mengurangi risiko penyebaran virus HIV \& AIDS di masyarakat dan memberi pemahaman yang benar mengenai penyakit HIV \& AIDS. Seperti yang diungkapkan oleh informan di bawah ini :

"Majelis Ulama sudah, sampai ke Wartawan pun media gathering kita ada, sampai ke komunitas motor, komunitas transgender, hampir semuanya kita sudah bertemu sama komunitas itu. "

(AA (66), KPAD)

Selain melakukan penyuluhan ke berbagai elemen masyarakat, KPAD Kabupaten Kotawaringin Timur juga membentuk komunitas "Warga peduli AIDS" di beberapa kelurahan dengan SK dari kecamatan. Warga peduli AIDS ini adalah suatu gerakan kepedulian warga terhadap penyebaran HIV \& AIDS di lingkungan masyarakat. Sementara di daerah yang menjadi tempat populasi kunci, yaitu 
di Kecamatan Pasir Putih "Pal 12", KPAD Kabupaten Kotawaringin Timur membentuk kelompok kerja (Pokja) yang diketuai oleh Ketua RT. Pokja ini membantu KPAD dalam sosialisasi dan pendistribusian kondom dengan pembentukan outlet kondom. Sebagaimana dijelaskan informan berikut:

"Warga peduli AIDS ini adalah suatu gerakan kepedulian..tentang penyebaran HIV \& AIDS. Jadi warga itu dia mengatasi di wilayah dia. " (AA (66), KPAD)

\section{"Kalau di Pal 12 kita ada bentuk Pokja, kita bentuk Pokja yang diketuai oleh ketua RT di situ jadi Pokja ini membantu perpanjangan tangan KPAD dalam hal ini misalnya pembentukan outlet Kondom" \\ (AA (66), KPAD)}

Secara rutin KPAD Kabupaten Kotawaringin Timur bekerjasama dengan lembaga Satpol PP juga melaksanakan kegiatan operasi Pekat (Penyakit Masyarakat) yang menyasar beberapa tempat penginapan dan hotel, serta beberapa titik rawan penularan penyakit HIV \& AIDS. Dari hasil operasi Pekat tersebut, yang terjaring kemudian diberikan pemahaman seputar HIV \& AIDS melalui kegiatan sosialisasi dan konseling dari konselor terlatih. Seperti dalam penjelasan informan berikut :

"KPA masuk memberikan sosialisasi tentang bahaya HIV \& AIDS, apa pengertiannya, bagaimana dampaknya, proses penularannya, supaya tahu. “ (AA (66), KPAD)

Peran lebih lanjut KPAD dalam penanggulangan HIV \& AIDS adalah upaya pengobatan atau rehabilitasi. Upaya ini dilakukan untuk mengurangi tingkat kematian di Kabupaten Kotawaringin Timur yang disebabkan oleh penyakit HIV \& AIDS. Bekerjasama dengan Dinas Kesehatan, pelayanan obat ARV diakui tidak lagi hanya dilaksanakan di Rumah Sakit, melainkan juga dapat di akses di Puskesmas tertentu. Namun baru satu Puskesmas yang memberikan pelayanan tersebut, yaitu Puskesmas Pasir Putih yang berlokasi dekat dengan lokalisasi Pal 12.
"Kalau Puskesmas, baru Pasir Putih. ARV nya masih terpusat di Rumah Sakit. Saran kita salah satu diantaranya dipertemukan, Rumah sakit, Dinas kesehatan, Puskesmas. Jadi langkah-langkah apa yang bisa kita lakukan setelah ini... bagaimana pembagaian ARV itu bisa nggak di bagi ke kecamatan di Puskesmas." (AA (66), KPAD)

Selain pelayanan dan pengobatan ARV yang dapat diakses dengan mudah di Puskesmas, pemberian ARV juga tidak lagi terbatas oleh standar nilai CD4, artinya berapa pun nilai CD4, pasien tetap akan diberikan pengobatan ARV secara maksimal. Namun untuk pelayanan rehabilitasi, Kabupaten Kotawaringin Timur belum mempunyai tempat secara khusus sehingga kegiatan rehabilitasi belum dapat terlaksana dengan baik oleh KPAD. Seperti yang diungkapkan informan di bawah ini :

"ODHA-nya ada, tapi nggak ada tempat khusus."

(AA (66), KPAD)

$\mathrm{P}$ a d a p e 1 a $\mathrm{k} \mathrm{s}$ a n a a n $\mathrm{p}$ a y a penanggulangan HIV \& AIDS di Kabupaten Kotawaringin Timur terdapat berbagai faktor penghambat yang dialami oleh KPAD, baik itu dalam hal pencegahan maupun pengobatan atau rehabilitasi. Hal ini dikarenakan berbagai macam kendala, yaitu pelayanan dan pengobatan ARV yang belum tersedia merata di semua wilayah atau Puskesmas kecamatan sehingga mengganggu program atau pelayanan yang diberikan. Selain itu, peran dari Stake holder pemangku kepentingan dalam penanggulangan HIV \& AIDS yang masih belum senada. Seperti dijelaskan oleh informan berikut.

"Koordinasi sudah ada memang,

cuma ini yang kita pehatikan

penekanan oleh Stake holder

pemangku kepentingan yang berbedabeda." (FC (48), Dinkes)

Dilain sisi, hambatan juga disebabkan oleh keberadaan lokalisasi di beberapa wilayah yang menjadi salah satu sumber utama penularan dan penyebaran penyakit HIV \& AIDS. Lokalisasi tersebut berada di 4 wilayah di 3 Kecamatan, yaitu Pal 12 Pasir Putih, Parenggean, Antang Kalang, dan 
Tangar. Dengan jumlah penghuni terbesar ada di Pal 12 Pasir Putih dengan 196 PSK. Seperti diungkapkan oleh kedua informan berikut.

"Data yang sudah didapat oleh mereka Dinas Sosial dan Ketenagakerjaan, di lokalisasi Kilometer 12 (Pal 12) itu ada 196 PSK, di Parenggean ada 52, di Parenggean itu km 12 rasanya, dari arah Kecamatan Antang Kalang hampir mendekati Parenggean itu 52 PSK, lalu di Tangar kurang lebih ada 43 kalau tidak salah saya ya 43 PSK." (R (40), DPRD)

"Kalau di Kotim ya di Tangar, Mentaya Hulu, sama Parenggean. 3 kecamatan itu, tapi yang paling banyak PSK nya ya di Pal 12, kalau di Tangar sedikit." (AA (66), KPAD)

Namun wacana penutupan atas keberadaan lokalisasi masih menjadi polemik di berbagai kalangan, hal ini karena dianggap dapat menghambat program pengawasan dan kontrol terhadap penyebaran penyakit HIV \& AIDS, dengan kata lain persebaran dan kesehatan PSK akan semakin susah dipantau jika lokalisasi ditutup. Hal ini sebagaimana diungkapkan oleh beberapa informan berikut.

"Contoh, Dolly tutup. Sekarang di Surabaya itu berkeliaran di Hotelhotel, itukan salah satu dampak penutupan itu." (SN (58), Asisten Pemkab)

"KPAD akan kesulitan, kesehatan

kesulitan,untuk melakukan screening dan pemeriksaan status kesehatannya."

(AA (66), KPAD)

"Ini kan hubungannya dengan ekonomi, kamu tutup prostitusi lalu mereka sibuk cari makan, mereka tambah parah, Dinas Sosial, Dinas Kesehatan ngawasinnya susah." (FC (48), Dinkes)

Program penanggulangan HIV \& AIDS di Kabupaten Kotawaringin Timur juga terhambat oleh dukungan dana dari pemerintah daerah yang masih sangat minim, serta keberadaan Perda yang mengatur secara khusus mengenai penanggulangan HIV \& AIDS yang masih belum tersedia. Sebagaimana dijelaskan oleh kedua informan berikut.

"Hambatan memang sementara tergantung pada faktor dukungan dana kita yang direncanakan oleh pemerintah."

(AA (66), KPAD)

"Terkait dengan HIV \& AIDS kami (DPRD) belum melakukan langkahlangkah yang dimaksud (Penerbitan Perda), sebelum ada kajian-kajian dari Dinas yang berhubungan dengan kasus itu."

(DS (35), DPRD)

\section{PEMBAHASAN}

Program HIV \& AIDS yang dilakukan oleh KPAD Kabupaten Kotawaringin Timur berlandaskan pada tiga pilar Indonesia Sehat. Yaitu pertama, Paradigma Sehat, dilakukan dengan strategi pengarusutamaan kesehatan dalam pembangunan kesehatan, penguatan promotif, preventif dan pemberdayaan masyarakat. Kedua, Penguatan Pelayanan Kesehatan, dilakukan dengan strategi peningkatan akses terhadap pelayanan kesehatan, optimalisasi sistem rujukan dan pendekatan continuum of care, intervensi berbasis pada risiko kesehatan. Terakhir, Jaminan Kesehatan Nasional (JKN) dilakukan dengan strategi perluasan sasaran dan manfaat, serta kendali terhadap kualitas mutu dan biaya. Dari program nasional Indonesia Sehat tersebut, KPAD Kabupaten Kotawaringin Timur memfokuskan pada program yang terdapat pada pilar pertama, yaitu pilar Paradigma Sehat, yang dilakukan melalui penguatan di bidang promotif, preventif dan pemberdayaan masyarakat. Hal ini dilakukan agar masyarakat mampu meningkatkan kesadaran, kemauan, kemampuan serta kemandirian dalam upaya penanggulangan HIV \& AIDS.

Menurut Hiola (2011) persepsi diri dan sosial tentang demoralisasi dan desakralisasi hubungan seks telah menyeret masyarakat pada penyimpangan seksual menjadi seks ekstra marital (seks bebas). Hal ini menjadi faktor yang mempengaruhi tingkat penambahan kelompok orang yang rawan terjangkit oleh penyakit HIV \& 
AIDS. Lebih lanjut diungkapkan bahwa tindakan penanggulangan HIV \& AIDS akan berbeda bagi setiap Negara, akan tetapi pada umumnya cara yang terbaik adalah melalui kegiatan intervensi pendidikan yang ditujukan untuk mengubah pola hidup dan perilaku seksual dari kelompok individu tertentu menjadi pola dan perilaku hidup sehat.

KPAD Kabupaten Kotawaringin Timur juga secara rutin melakukan berbagai usaha sosialisasi ke berbagai elemen sektor masyarakat. Dimulai dari komunitas, Perguruan Tinggi, Pelajar, Mahasiswa, Ibuibu pengajian, Organda, Majelis Ulama hingga Media. Berbagai usaha sosialisasi tersebut memberi penekanan pada pentingnya perilaku bertanggung jawab dalam rangka melawan penularan HIV \& AIDS. Dalam hal ini, baik individu, pemerintah, media massa dan sektor lainnya, semua memiliki tanggung jawab yang penting untuk mencegah penyebaran virus HIV \& AIDS (Hiola, 2011).

Adapun serangkaian kegiatan yang direncanakan dan dilaksanakan dalam melaksanakan penyuluhan kesehatan meliputi : Pertama, peningkatan komunikasi dan penyebarluasan informasi kesehatan. Kedua, peningkatan peran serta dan swadaya masyarakat. Ketiga, pembinaan dan pengembangan kemampuan edukatif petugas-petugas non kesehatan dan pengelolaan program.

Dari kegiatan penyuluhan kesehatan tersebut dapat dilihat ada unsur informasi dan motivasi. Unsur informasi tercermin dari kegiatan yang ditujukan untuk peningkatan komunikasi dan penyebarluasan informasi kesehatan. Sedangkan unsur motivasi terlihat pada tujuan penyuluhan untuk menjadikan pola hidup sehat sebagai kebiasaan hidup (perilaku) sehari-hari di masyarakat, agar masyarakat mampu untuk ikut berperan serta dalam berbagai usaha perbaikan kesehatan (Saputri, 2015).

Peran dan kemandirian masyarakat dalam penanggulangan HIV \& AIDS amatlah penting, karena lembaga atau wadah yang ada di masyarakat hanya dapat memotivasi, mendukung dan membimbingnya (Notoatmodjo, 2007). Peran itulah yang kemudian ditangkap oleh
KPAD Kabupaten Kotawaringin Timur dengan membentuk kelompok masyarakat yang peduli dengan penyebaran HIV \& AIDS dengan membentuk wadah yang disebut "Warga Peduli AIDS". Wadah ini dibentuk di setiap kelurahan melalui SK Camat dengan 3 peran utama warga, yaitu identifikasi potensi risiko di wilayah tugas, edukasi dan fasilitasi ke layanan kesehatan, serta memastikan dengan baik tidak ada stigma dan diskriminasi bagi siapa pun di lingkungan masyarakat. Jika dicermati program ini telah sesuai dengan STRANAS Penanggulangan HIV \& AIDS dimana ditegaskan upaya penanggulangan HIV \& AIDS diselenggarakan oleh masyarakat sipil dan pemerintah berdasarkan prinsip kemitraan. Selain membentuk kelompok "Warga Peduli AIDS" di masyarakat, KPAD juga membentuk kelompok kerja (Pokja) pada populasi kunci yang berada di wilayah lokalisasi "Pal 12" Kecamatan Pasir Putih yang diketuai oleh Ketua RT.

Peran dalam hal pelayanan dan pengobatan, KPAD bersama pemerintah memberikan pelayanan ARV yang diberikan tidak terbatas pada standar minimal nilai CD4, namun tidak semua puskesmas atau kecamatan yang memberikan pelayanan ARV. Pelayanan ini diakui baru terdapat di RSUD yang terletak di ibukota Kabupaten dan Puskesmas Pasir Putih "Pal 12" yang terletak dekat dengan populasi kunci. Kemudahan mendapat akses pelayanan ini penting dalam upaya pencegahan penyakit HIV \& AIDS, dalam model Green disebutkan bahwa faktor kemudahan akses pelayanan kesehatan akan mempengaruhi pemanfaatan pelayanan kesehatan (Pradipta, 2013). Kemudahan dalam mengakses sarana dan prasarana juga merupakan hal yang sangat penting, karena ketersediaan sarana dan prasarana yang memadai akan percuma jika tidak mudah untuk diakses. Hal itu tidak akan berdampak kepada efektivitas dan efisiensi dari upaya menanggulangi dan mencegah keberadaan penyakit HIV \& AIDS (Saputri, 2015).

Akses terhadap pelayanan tidak hanya terkait dengan permasalahan seberapa jauh dan dekat jarak, namun terdapat dua faktor penentu (determinan) yaitu determinan penyediaan yang merupakan faktor 
pelayanan dan determinan permintaan yang merupakan faktor pengguna. Determinan penyediaan terdiri atas organisasi pelayanan dan infrastruktur fisik, tempat pelayanan, ketersediaan, pemanfaatan dan distribusi petugas, biaya pelayanan serta mutu pelayanan. Sedangkan determinan permintaan yang merupakan faktor pengguna meliputi rendahnya pendidikan dan kondisi sosial budaya masyarakat serta tingkat pendapatan masyarakat yang rendah atau miskin. Kebutuhan primer agar memperoleh akses pelayanan yang efektif adalah ketersediaan fasilitas dan petugas, jarak dan finansial terjangkau serta masalah sosial budaya yang dapat diterima oleh pengguna (Suharmiati,2013).

Pelayanan kesehatan yang bermutu di Indonesia saat ini memang harus diakui hanya dapat diperoleh oleh kalangan masyarakat yang memiliki akses ke sarana pelayanan kesehatan berkualitas. Yaitu dilihat dari akses geografis, yang hanya dapat diakses di beberapa kota besar yang memiliki sarana dan klinisi yang lengkap dan kompeten. Akses pembiayaan yang hanya kalangan menengah atas yang dapat membayar out-of-pocket. Akses hubungan baik, yaitu hanya sejawat dokter atau keluarga dokter yang mampu mendapatkan pelayanan "seperti keluarga sendiri". Serta akses informasi yang hanya orang-orang tertentu yang dapat memperoleh informasi dari kualitas sarana pelayanan kesehatan tertent dan berbagai kemampuan terhadap akses khusus lainnya (Utarini, 2011).

Pengobatan terhadap HIV \& AIDS sendiri memiliki keunikan yang perlu mendapat perhatian khusus dari para penyelenggara pelayanan, seperti misalnya terapi ARV yang merupakan pengobatan seumur hidup dan memerlukan pendekatan perawatan kronik yang khusus, serta tuntutan terhadap kepatuhan pada pengobatan ARV yang sangat tinggi yaitu diatas $95 \%$, hal ini guna menghindari resistensi virus terhadap obat dan kegagalan terapi ARV. Terapi ARV selain akan meningkatkan kebutuhan akan layanan konseling dan tes HIV juga akan meningkatkan jumlah kegiatan pencegahan dan peran serta ODHA (Kemenkes, 2012). Agar tingkat kepatuhan pada terapi ARV dan kualitas hidup ODHA dapat meningkat secara optimal, maka perlu dikembangkan suatu layanan perawatan yang komprehensif dan berkesinambungan.

KPAD dalam pelayanan rehabilitasi belum melaksanakan dengan baik, hal ini disebabkan oleh pusat rehabilitasi yang menjadi tempat khusus pelayanan belum tersedia. Keberadaan pusat rehabilitasi ini penting karena dapat menjadi instrumen dalam mengatasi permasalahan stigma dan diskriminasi yang terjadi di masyarakat. Rehabilitasi dapat dilakukan dengan perawatan yang dilakukan bersama dengan program eliminasi melalui program Pencegahan, dan Kelompok Perawatan Diri (KPD) atau Self Care Group. Rehabilitasi ini diharapkan dapat mengurangi masalah psikologis, serta stigma sosial, agar kualitas hidup ODHA meningkat dan dapat berintegrasi dengan kehidupan sosial (Murtaqib, 2015).

Berbagai faktor yang masih menjadi kendala dalam program penanggulangan HIV \& AIDS di Kabupaten Kotawaringin Timur salah satunya adalah keberadaan lokalisasi yang menjadi determinan penting dalam penyebaran penyakit HIV \& AIDS. Lokalisasi menurut Hawari (2006) merupakan suatu tempat dimana para Pekerja Seks Komersial (PSK) melakukan kegiatan pelacuran. Umumnya tempat tersebut terdiri atas beberapa rumah kecil atau tenda yang dikelola oleh Mucikari atau yang biasa dikenal dengan sebutan Germo. Di dalam tempat tersebut tersedia beberapa fasilitas seperti perlengkapan tidur, kursi tamu, pakaian, alat berhias, serta para PSK. Keberadaan lokalisasi dalam jumlah yang besar di suatu daerah berpengaruh besar bagi lingkungan sekitar terutama bagi kelompok usia remaja. Sementara itu, lingkungan merupakan salah satu faktor pendorong yang dapat menjadi negatif atau positif terhadap seseorang. Hal itu yang membuat pengaruh lingkungan begitu besar dan menentukan bagi kemajuan suatu masyarakat, terutama masyarakat yang tinggal di sekitar wilayah lokalisasi (Retno, 2013).

Lokalisasi pada umumnya merupakan tempat yang terisolir atau terpisah dari komplek penduduk lainnya. Tujuan dibentuk lokalisasi adalah untuk menjauhkan masyarakat umum terutama usia anak dan 
kelompok usia yang sedang dalam masa pubertas, dan remaja dewasa dari berbagai macam pengaruh yang tidak sesuai atau bermoral dan pengaruh dari kegiatan pelacuran, menghindarkan gangguan dari kaum pria hidung belang terhadap wanita baik, memudahkan pengawasan kepada para PSK terutama yang menyangkut kesehatan dan keamanan mereka, memudahkan tindakan preventif terhadap penyakit menular seksual (PMS), mencegah pemerasan terhadap para PSK, yang pada umumnya selalu menjadi pihak yang paling lemah di kelompok masyarakat (Kartono, 2003).

Namun lokalisasi jika ditutup juga akan memberikan dampak negatif, berdasarkan laporan penelitian Sugiyono (2015) dampak negatif penutupan lokalisasi antara lain adalah mempengaruhi penghasilan warga eks lokalisasi dan berdampak pada menurunnya penghasilan dari warga yang menggantungkan hidup pada kegiatan di lokalisasi. Selain itu juga akan memunculkan transaksi prostitusi yang dilakukan secara sembunyi pada eks lokalisasi. Secara tidak langsung juga mendorong kemunculan hotspot (tempat) baru dan bentuk baru dalam cara bertransaksi. Penutupan lokalisasi juga akan menghentikan pemantauan kesehatan di eks lokalisasi, serta adanya rasa traumatis dan ketakutan pada para PSK/WPS/PS yang beroperasi di wilayah eks lokalisasi.

Faktor penghambat penanggulangan HIV \& AIDS yang lain adalah pendanaan. Kendati telah mendapat sokongan dana dari lembaga donor internasional yaitu bantuan grant atau hibah dari "The Global Fund to Fight AIDS", namun pendanaan tersebut masih belum mencukupi. Di samping sumber daya, pengelolaan dana bantuan hibah juga bergantung pada budaya organisasi, karena keberhasilan penerapan suatu pengelolaan dana bantuan erat kaitannya dengan budaya organisasi. Dari beberapa hasil penelitian yang telah dilakukan menunjukkan bahwa budaya organisasi merupakan determinan penting yang berpengaruh terhadap kinerja organisasi sektor publik (Brewer dan Selden, 2000).

Selanjutnya faktor penghambat lain adalah peran Stake holder yang masih kurang. Peran dari Stake holder mempunyai kedudukan yang sangat penting dalam merealisasikan program penanggulangan HIV \& AIDS yang akan dilaksanakan. Stake holder dalam kebijakan penanggulangan HIV \& AIDS tersebut terdiri dari, pertama Stake holder sekunder yang terdiri dari beberapa lembaga pemerintah, kelompok kerja, dan Lembaga Swadaya Masyarakat (LSM). Kedua, Stake holder primer yakni seseorang atau kelompok yang memiliki risiko tinggi dan rentan akan tertular (vulnerable people), orang yang tertular (infected people), dan masyarakat umum (Purnomo, dkk, 2015).

Faktor penting lainnya yang menjadi penghambat adalah belum adanya Perda yang mengatur secara khusus dan spesifik mengenai hal yang terkait penanggulangan HIV \& AIDS di Kabupaten Kotawaringin Timur. Sebagai negara hukum, pembentukan peraturan perundang-undangan merupakan suatu hal yang sangat penting demi terselenggaranya roda pemerintahan yang baik terlebih bagi negara yang menerapkan sistem parlementer dan desentralisasi seperti di Indonesia. Pada konteks daerah, terdapat beberapa jenis produk hukum daerah dan salah satu diantaranya adalah Perda, yang menurut Undang-undang No. 12 Tahun 2011 tentang Pembentukan Peraturan Perundangundangan, Perda adalah Peraturan Perundang-undangan yang dibentuk atas persetujuan bersama antara Dewan Perwakilan Rakyat Daerah (DPRD) bersama Kepala Daerah. Keberadaan Perda ini amat penting dikarenakan kedudukan Perda yang lebih tinggi dibanding produk hukum daerah lainnya. Perda memiliki sifat mengikat secara yuridis ke luar dan ke dalam, sehingga mengikat masyarakat luas untuk menaatinya. Perda juga mempunyai konsekuensi tinggi terhadap pengalokasian anggaran belanja daerah (APBD). Selain itu, Perda dapat dijadikan landasan formal dalam penegakan upaya hukum karena telah mengandung sanksi dan mekanisme penyelidikan, penyidikan dan penjatuhan sanksi (USAID, 2008).

Pembuatan Perda Penanggulangan HIV \& AIDS harus memperhatikan tiga asas prioritas yaitu asas kemanusiaan, asas keadilan, dan asas kesamaan kedudukan dalam hukum dan pemerintahan. Maka 
perlindungan, penghormatan dan pemenuhan atas asas-asas tersebut harus dipenuhi atau dicantumkan. Asas tersebut antara lain adalah, Pertama, stigma, yaitu pengucilan terhadap orang atau kelompok orang tertentu dengan memberi cap (pelabelan) atau julukan tertentu tanpa alasan yang sah menurut ketentuan hukum. Kedua, diskriminasi, yaitu setiap pembatasan, pelecehan atau pengucilan yang dilakukan secara langsung ataupun tidak langsung yang didasarkan pada pembedaan manusia atas dasar agama, suku, ras etnik kelompok, golongan status sosial, status ekonomi, jenis kelamin, bahasa, serta keyakinan politik, yang berakibat pengurangan, pengakuan pelaksanaan atau penggunaan Hak Asasi Manusia (HAM) dan kebebasan dasar dalam berkehidupan, baik individual maupun kolektif dalam bidang politik, ekonomi, hukum, sosial, budaya dan aspek kehidupan lain. Ketiga, Penyiksaan, yaitu setiap perbuatan yang dilakukan dengan maksud sengaja sehingga menimbulkan rasa sakit atau penderitaan yang hebat baik jasmani maupun rohani pada seseorang, yang ditujukan untuk memperoleh pengakuan atau keterangan dari seseorang atau orang ketiga dengan menghukum (menyiksa) atas perbuatan yang telah dilakukan, atau diduga telah dilakukan oleh seseorang atau orang ketiga, dan atau suatu alasan yang didasarkan pada setiap bentuk diskriminasi.

Perda Penanggulangan HIV \& AIDS dapat dibentuk melalui beberapa tahapan dari proses fungsi legislasi DPRD. Lebih lanjut Asshiddiqie (2006) mengemukakan bahwa fungsi legislasi menyangkut empat bentuk kegiatan, yaitu Pertama, prakarsa pembuatan Undang-undang (legislative initiation); Kedua, pembahasan rancangan Undangundang (law making process); Ketiga, persetujuan atas pengesahan rancangan Undang-undang (law enactment approval). Dan Keempat, pemberian persetujuan pengikatan atau ratifikasi atas perjanjian atau persetujuan internasional dan dokumen hukum yang mengikat lainnya. Salah satu yang terlebih dahulu harus masuk dalam tahapan fungsi legislasi tersebut adalah, draft Perda masuk ke dalam penyusunan Program Legislasi daerah (Prolegda).

Walaupun secara normatif produk Perda sebagai hasil dari fungsi legislasi, namun kepentingan politik (political interest) dari berbagai kelompok partai yang ada di dalamnya sangat mewarnai pencapaian kepentingan tersebut, dan hal ini seringkali diperparah oleh hubungan simbiosis yang tidak baik antara eksekutif yang dipimpin oleh Kepala Daerah yang berasal dari partai tertentu dengan para anggota legislatif, yang kemudian akan sangat menentukan warna dan tujuan dari Perda tersebut. Hubungan dari aktor dan peranannya (kekuasaan) sebagai pengambil keputusan adalah sangat tergantung dari warna dan kompromi politik yang terjadi, daripada yang berkaitan dengan materi dalam musyawarah atau debat kebijakan yang masuk diakal, logis, dan berdasar fakta dan data yang terdapat di lapangan. Sehingga komitmen yang hanya berdasar pada psikologis individu atau pribadi juga harus didukung oleh komitmen yang bermuatan atau mempunyai nilai dalam kedudukan hukum.

\section{KESIMPULAN}

Pada penelitian ini dapat disimpulkan bahwa peran KPAD dalam upaya penanggulangan di Kabupaten Kotawaringin Timur yaitu dilakukan melalui sosialisasi dan penyuluhan HIV dan AIDS di berbagai elemen masyarakat, pembentukan POKJA di wilayah Pal 12, serta membentuk kelompok "Warga Peduli AIDS" di masyarakat. Peran pengobatan atau rehabilitasi, KPAD bekerjasama dengan Dinas Kesehatan memberikan pelayanan ARV tidak terbatas pada nilai minimal CD4, namun belum memiliki tempat khusus untuk pelayanan rehabilitasi.

Berbagai faktor yang menjadi penghambat adalah keberadaan lokalisasi dalam jumlah besar yang terdapat di beberapa wilayah kecamatan dan menjadi determinan penting penyebaran kasus HIV \& AIDS, belum tersedianya pelayanan dan pengobatan ARV di Puskesmas di semua wilayah kecamatan, kerjasama lintas sektoral yang kurang, belum adanya Perda 
yang mengatur secara khusus mengenai penanggulangan HIV \& AIDS, serta dukungan dana yang masih sangat minim.

\section{SARAN}

KPAD Kabupaten Kotawaringin Timur diharapkan dapat segera membentuk tim khusus bersama lembaga terkait yang berada dalam lingkungan Pemkab Kotawaringin Timur, untuk segera membahas dan menyiapkan draft Perda agar dapat masuk dalam Prolegda DPRD Kabupaten Kotawaringin Timur, selain itu KPAD Kabupaten Kotawaringin Timur diharapkan dapat melibatkan media massa lokal secara intens sebagai media sosialiasi terkait penyakit dan penanggulangan HIV \& AIDS. Untuk peneliti selanjutnya diharapkan dapat lebih dalam mengkaji mekanisme pembentukan Perda penanggulangan HIV \& AIDS terutama pada implementasi dan penerapan sanksi yang efektif.

\section{DAFTAR PUSTAKA}

Asshiddiqie, J. 2006. Pengantar Ilmu Hukum Tata Negara. Jilid II. Sekretariat Jenderal dan Kepaniteraan MK RI. Jakarta.

Brewer, G.A. and S.C. Selden. 2000. Why Elephants Gallop: Assessing and Predicting Organizational Performance in Federal Agencies. Journal of Public Administration Research and Theory.

Hawari, D. 2006. Global Effect HIV \& AIDS Dimensi Psikoreligi. Fakultas Kedokteran Universitas Indonesia. Jakarta.

Hiola. R. 2011. Penanggulangan Masalah AIDS dan Penularannya Pada Remaja. Jurnal Health \& Sport, Vol. 11, Nomor 2. Fakultas Kesehatan Masyarakat Universitas Negeri Gorontalo . Gorontalo.

Kartono, K. 2003. Patologi Sosial 1. Rajawali Press. Jakarta.

Kemenkes. 2012. Pedoman Penerapan Layanan Komprehensif HIV-IMS Berkesinambungan. Kementerian Kesehatan. Jakarta.

Murtaqib. 2015. Model Rehabilitasi Klien HIV \& AIDS Berbasis Komunitas. Universitas Jember. Jember.
Mynarwati. 2000. Surveilans dalam penanggulangan HIV \& AIDS di Indonesia. Jurnal Yarsi University. Jakarta.

Notoatmodjo, S. 2007. Promosi Kesehatan dan Ilmu Perilaku. Rineka Cipta. Jakarta.

Pradipta, M.N. 2013. Faktor-Faktor Yang Mempengaruhi Konsistensi Pemakaian Kondom Pada Waria Binaan Puskesmas Bogor Timur Dalam Upaya Pencegahan HIV \& AIDS Tahun 2012. Fakultas Kesehatan Masyarakat. Universitas Indonesia. Depok.

Profil Kesehatan Kabupaten Kotawaringin Timur tahun 2014.

Profil Kesehatan Provinsi Kalimantan Tengah tahun 2012.

Puadi, A. 2016. Kajian Kesiapan Penerbitan Perda Penanggulangan HIV \& AIDS di Kabupaten Kotawaringin Timur. Skripsi. Fakultas Kesehatan Masyarakat, Universitas Airlangga. Surabaya.

Purnomo. D, Soeaidy. M.S, Hadi. M. 2015. Analisis Kebijakan Penanggulangan HIV \& AIDS di Kabupaten Malang, Studi Pelaksanaan Peraturan Daerah Nomor 14 Tahun 2008 Kabupaten Malang. Jurnal Administrasi Publik, Fakultas Ilmu Administrasi, Universitas Brawijaya. Malang.

Retno, J. 2013. Pengetahuan Remaja Tentang HIV \& AIDS, Studi Kasus Pada Remaja di Lingkungan.

Lokalisasi Land Craft Machine di Dusun Krajan RT 01/RW 03, Desa Bulusan, Kecamatan Kalipuro, Kabupaten Banyuwangi. Jurnal Fakultas Ilmu Sosial dan Ilmu Politik, Universitas Jember. Jember.

S a putri, L. 2015 . Peran Kom is i Penanggulangan AIDS (KPA) dalam Pencegahan dan Penanggulangan HIV \& AIDS di Kota Samarinda. Jurnal Administrasi Negara. Fakultas Ilmu Sosial dan Politik. Universitas Mulawarman.

Soekamto, S. 2010. Sosiologi Suatu Pengantar. PT Raja Grafindo Persada. Jakarta.

STRANAS Penanggulangan HIV \& AIDS 2007-2010. 
Sugiyono. 2015. Dampak Sosial Penutupan Lokalisasi Di Kabupaten Banyuwangi, Studi Kasus Tentang Faktor Penyebab Mantan PSK Kembali Bekerja Di Lokalisasi Turian Purwoharjo Banyuwangi. Jurnal Hukum Islam, Ekonomi Dan Bisnis, Istiqro.

Suharmiati. 2013. Review Kebijakan Tentang Pelayanan Kesehatan Puskesmas di Daerah Terpencil Perbatasan. Buletin Penelitian Sistem Kesehatan. Pusat Humaniora, Kebijakan Kesehatan dan
Pemberdayaan Masyarakat Kemenkes RI. Surabaya.

Undang-undang Kesehatan No. 36 Tahun 2009, Tentang Wabah Penyakit Menular USAID. 2008. Elemen-Elemen Pokok Pembentukan Peraturan Daerah Tentang Penanggulangan HIV \& AIDS. Utarini, A. 2011. Bagaimana Caranya

Menyediakan Pelayanan Kesehatan yang Bermutu untuk Semua Orang ?. Universitas Gadjah Mada. Yogyakarta. 